\title{
Assessment of Adaptive Reuse of Heritage Shop Houses for Sleep Lodging in Malaysia: Fulfilment of Conservation Guidelines
}

\author{
M.A. Othuman Mydin ${ }^{1, a}$, N.A. Keling ${ }^{2}$, N. Md. Sani ${ }^{3}$, N.F Abas ${ }^{4}$ \\ ${ }^{1,2,3,4}$ School of Housing, Building and Planning, Universiti Sains Malaysia, 11800, Penang, Malaysia
}

\begin{abstract}
This study focuses on the compliance of adaptive reuse of historic shop houses for sleep lodging with reference to the Guidelines for Conservation Areas and Heritage Buildings by Majlis Perbandaran Pulau Pinang (MPPP). Through this research, awareness towards the compliance of building conservation guidelines for heritage shop houses will be clarified accordingly. The goal of this study is to determine and extract vital clauses and components of Guidelines for Conservation Areas and Heritage Buildings (GCAHB) towards adaptive reuse of heritage shop houses so that revitalization of these buildings can be ensured when changing the original function of the property. The aim is also to evaluate the compliance of the adaptive reuse of heritage shop houses with the GCAHB, and, lastly, to provide recommendations for adaptive reuse of heritage shop houses, also in compliance with the GCAHB. Additionally, heritage building owners can use this dissertation as a reference whenever they intend to adaptively reuse their buildings. Furthermore, recommendations in this research could be used for future reference.
\end{abstract}

\section{Introduction}

Malaysia has a lot of historical buildings, each with its own story and value [1]. These historical buildings have an extraordinary architectural style that needs to be conserved in order to appreciate the style of past workmanship and historic features, as it will be a testament of local history for future generations [2]. Since the United Nations Educational, Scientific and Cultural Organization (UNESCO) has selected a few states in Malaysia as 'World Heritage Sites', a number of conservation works have rapidly progressed thanks to self-awareness among Malaysians. Penang, Malacca and Taiping, Perak are the states that have contributed most to conservation works since they are the state that have been given the 'World Heritage Site' title [3]. Strategic planning was conceived as well in order to ensure the smooth proceeding of this effort.

Therefore, the government put serious focus on conservation works by establishing the National Heritage Act 2005 (formerly known as the Antiquity Act 1976) [4]. Accordingly, all states need to prepare their own manual or guidelines based on the National Heritage Act 2005 for conservation works. For example, the Municipal Council of Penang has provided conservation guidelines for historical building owners known as 'Guidelines for Conservation Areas and Heritage Buildings' as a reference for heritage building owners [5]. These guidelines cover standards from the internal to external parts of each building.

\footnotetext{
${ }^{\mathrm{a}}$ Corresponding author : azree@usm.my
} 
Due to the enormous number of conservation works in Penang, many people have neglected the required guidelines that were provided and have instead used different approaches for their buildings [6]. For example, The Rice Miller City Residences in Penang planned to re-adapt their heritage building into thirteen storeys, making it about thirty-nine meters tall which is over the height limit stated in the guidelines. The maximum height allowed in the guidelines is only eighteen metres, or roughly five storeys, for new buildings in the two zones: core zone and buffer zone [7]. Like this case, the same goes for three other buildings which are the Boustead Royale Bintang Hotel project behind the general post office in Lebuh Downing, the E\&O Hotel extension and the 23-storey Hotel in Jalan Sultan Ahmad Shah by the Low Yat Group located in the buffer zone. All of these are 84.4 metres high [8].

\section{Methodology}

To complete this research, a case study research methodology was used, in which several approaches were taken. The primary and secondary data were used as an additional medium to gain information for this research. The literature reviewed for reference in this study included articles, journals, books and internet sources related to building conservation. All the data from literature reviewed has played a key role in enhancing understanding of this study's subject, and therefore, has been used as a support medium for analysis in this study. For the case study, six historic shop houses around George Town which have been adapted for reuse were investigated and evaluated. This number of shop houses to be included in this case study depended on data saturation which, at the earliest stage of planning, included twelve heritage shop houses [9]. However, according to sampling limitations, the case study was then reduced to six cases only. Furthermore, some interview sessions were conducted with the building owners.

\section{Analysis and Discussion}

This section will focus on the changes done in the following case studies: Red Inn Heritage, Red Inn Penang, Rainbow Hotel on Pintal Tali Street, Ryokan Hotel on Muntri Street, Syok Hostel on Lebuh Chulia, and Red Inn Court on Masjid Kapitan Keling Street. Based on observations, it was determined that a various changes done to these buildings can be identified as post-conservation work. There were several changes to the structure, materials, space and mechanical and electrical systems of these buildings according to the Guidelines for the Conservation Areas and Heritage Buildings from the Draft George Town Special Area Plan.

\subsection{Forecourt}

According to Dr. Kamarul, forecourt is not a feature of heritage shop houses in George Town [10]. This is because the front facade of heritage shop houses extends to the street and is referred to as "five foot way." From the front, people can directly see features of common heritage shop houses such as columns, timber shutters, and roof tiles [11,12].

\subsection{Finishes and Colours}

There are only four buildings from the total six that follow the colour scheme as stated in the guidelines. The buildings that follow the requirements are Red Inn Penang, Red Inn Court, Ryokan and Rainbow Lodge. Those four structures are painted with a white colour to accentuate that the building is a heritage building. The other two buildings do not follow the requirements because their colours do not fall in line with the typical characteristics of heritage buildings. For example, the Syok Hostel building is painted a striking orange colour which is not part of the preferred colour scheme (Figure 1). The ideal colour scheme is soft or pastel colours which do not compromise the heritage value. Using vibrant colours may be good for attraction purposes, but, in terms of preserving the 
building's historical value, striking colours are not allowed. With regard to Red Inn Heritage, the building is not uniformly painted with the same colours. The front side is a creamy white colour while the side wall is a soft peach colour. The soft peach side is also not properly maintained as the paint has started to blister (Figure 2). Essentially, when too many colours are used, the aesthetic value of a heritage building will be ruined.

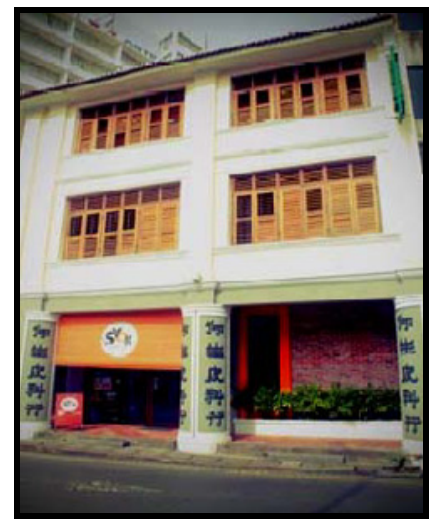

Figure 2: Syok Hostel uses bright orange for attraction

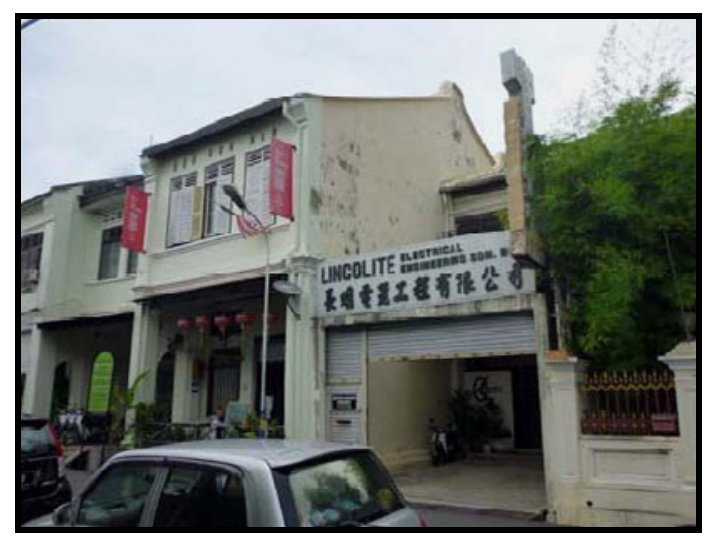

Figure 1: Red Inn Heritage does not uniformly painting their building with the same colours

\subsection{Colour Illustrations}

All six buildings in this case study have retained the original tiles with their original installation, but they have only managed to keep some of the terracotta roof tiles. The other part of the roofs has been replaced with metal roofing or corrugated polycarbonate roofs. For example, Rainbow lodge, Red Inn Court, Red Inn Heritage, and Red Inn Penang have all maintained terracotta tile on the front part of the roof, but in the middle and rear part they have used another type of roofing. Changes were made in roofing material because the owners wanted to allow in natural light and to save costs. Nowadays, terracotta tiles are quite expensive and hard to find, therefore, the alternative solution is to allow natural light to enter the building via corrugated polycarbonate which functions as a skylight. It is also a good way to enhance energy efficiency in heritage buildings (Figure 3).

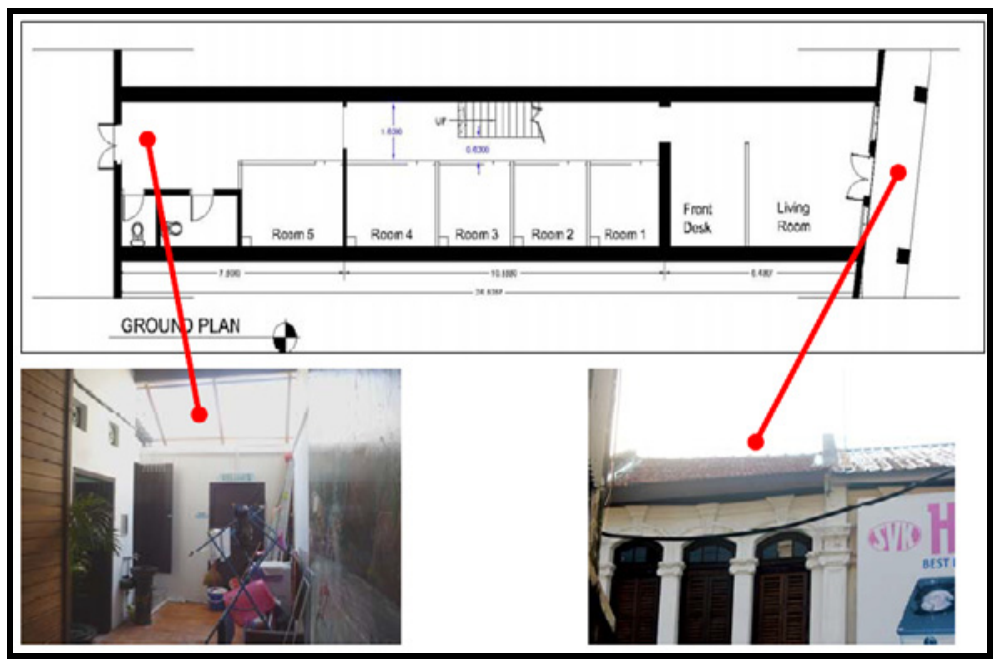

Figure 3: Example from the Rainbow Lodge of terracotta tiles in the picture on the right and corrugated polycarbonate skylight in the picture on the left 
For the Rainbow Lodge, Red Inn Court, Red Inn Heritage, and Red Inn Penang, it can be clearly seen that the roof structures have been retained and restored to their original form. For Syok Hostel and Ryokan, their roofs are difficult to see from below. A horizontal timber purlin has been installed between load-bearing walls from pillar to pillar for these four buildings. A roof ridge with raised vent brickwork can be seen on the Red Inn Heritage and Red Inn Penang (Figure 4). While for the Rainbow Lodge, a V-tiled over joint has been installed from the original structure (Figure 5). All these six cases comprise the latest Penang shop houses, so they contain a middle brickwork party wall which functions as a division with the neighbouring building. This party wall is important because it plays a role in passive fire prevention as it can slow down flames from spreading to the adjacent building.
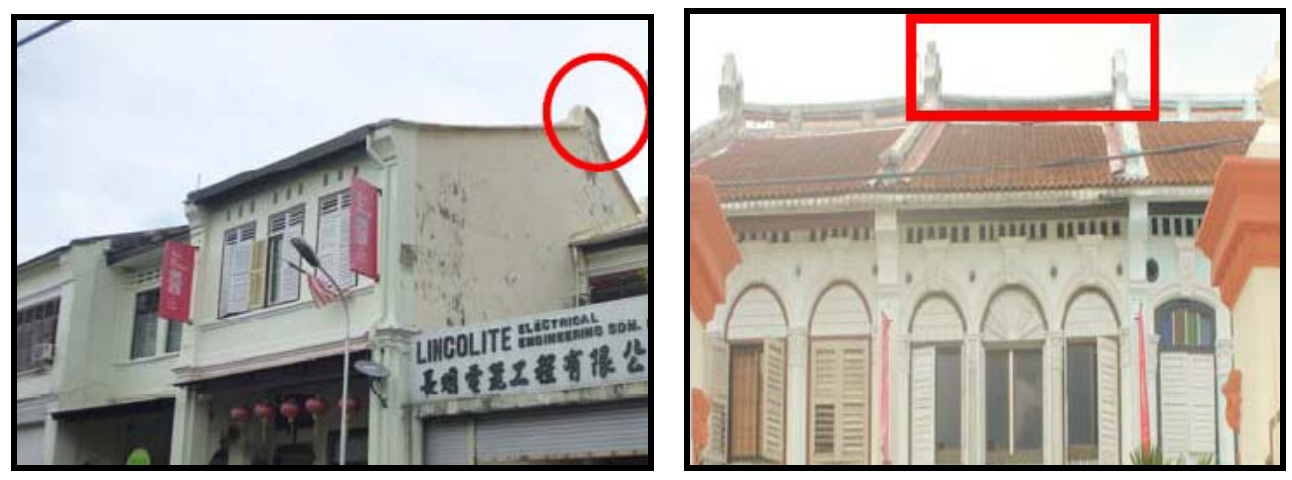

Figure 4: The left picture shows Red Inn Heritage while the picture on the right shows Red Inn Penang

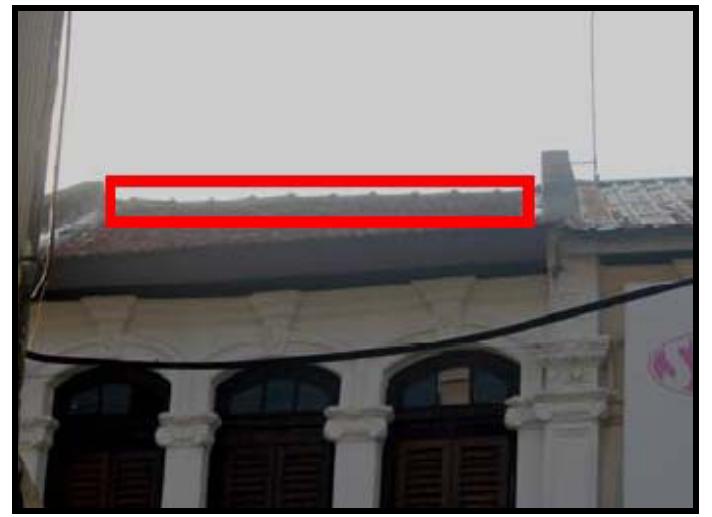

Figure 5: V-tiled over joint on the roof ridge of Rainbow Lodge

\subsection{Front / Side Facade}

A decorative feature located below the roof beam and on the first floor beam can be seen on facades of the Rainbow Lodge and Red Inn Penang. Both of these structures have decorative, lime mortar moulding. Decorative elements of the Rainbow Lodge and Red Inn Penang include framed arches with central keystones, whereas the Red Inn Court only has arches as its decorative feature. The decorative features of these three buildings have been retained and repainted with the same colour and painting medium used on the walls. The other three sleeping lodges do not have this decorative feature because they are of different architectural styles.

Mostly, buildings that use fixed louver, timber shutters do not have balustrades because the height of the shutter is not very high and the function of balustrades is to prevent people from falling down accidentally. This type of shutter was used by the Ryokan Chic Hostel, Red Inn Court and Rainbow Lodge. However, the Rainbow Lodge has not repaired or reinstated the missing balustrades. Plus, this 
sleeping lodge does not have new secondary, internal windows located behind the timber shutter (Figure 6a). The same is true for the Red Inn Court, but for the Ryokan Chic Hostel, internal windows were installed for air-conditioning purposes and to reduce the entering of external noise into the building. New secondary windows have also been applied to the Red Inn Penang, Syok Hostel and Red Inn Heritage (Figure 6b). The Red Inn Penang has balustrades unlike Syok Hostel where no balustrades have been installed. For the Red Inn Heritage, the balustrades have been replaced with window grills made from cast iron (Figure 6c).

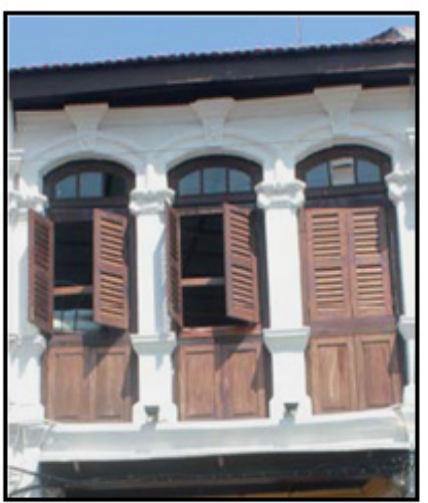

a)

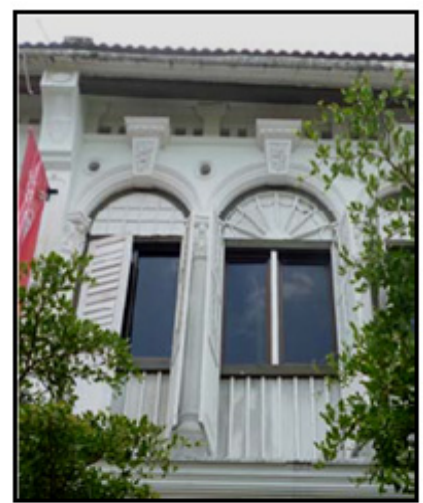

b)

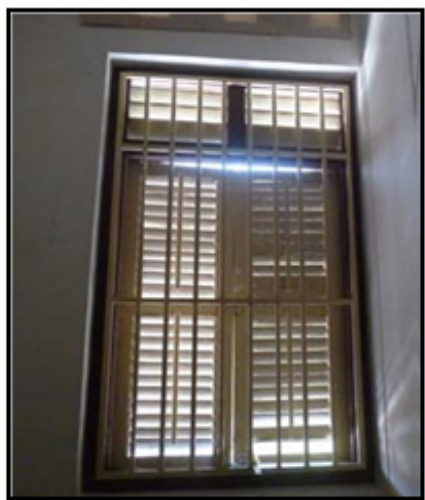

c)

Figure 6: Actual condition of façade at Rainbow Lodge, Red Inn Penang and Red-Inn Heritage buildings a) Missing balustrade-Rainbow Lodge b) secondary window-Red Inn Penang c) cast iron grill-Red Inn Heritage

The side facade for Rainbow Lodge is quite dangerous because there is no proper attachment to the adjacent building. From below, a large gap with improper finishing on the side façade can be seen. This area is exposed to the rain and hot weather, therefore, without proper finishing; the structure of the side facade may become damaged. The current situation shows the paint on the surface has started to blister and yellow residue is present due to dampness.

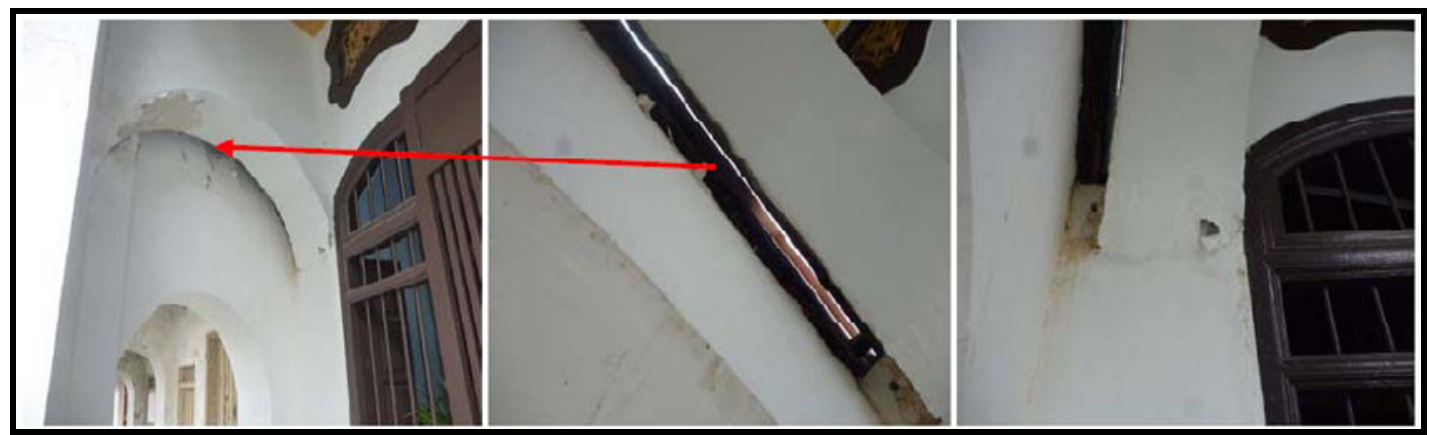

Figure 7: Gap between the left side of Rainbow Lodge and the adjacent building

\subsection{Five Foot Way - Veranda}

Heritage shop houses are famous for their five foot way feature. Ranging from Early Penang style until Late Penang style, all shop houses must have a five foot way. The function of the five foot way is to provide shelter from the weather located under the first floor ceiling. The five foot way is also a place for unloading goods and for public pedestrian traffic. It is called five foot way because the standard measurement of width is five foot or 1.5 meters. However, the measurements for the buildings in this case study different from one to another. This may have happened due to the length 
and size of the buildings. The measurements for the buildings in this study are: Rainbow Lodge 1.5 meters, Red Inn Court 2.2 meters, Red Inn Heritage 1.9 meters, Red Inn Penang 2.0 meters, Ryokan Chic Hostel 1.8 meters and, lastly, Syok Hostel 2.0 meters.

Lime plaster was used for the finishing material of the wall located along the five foot way for all but one of these structures. Unlike the rest, Syok Hostel uses a glass wall for its five foot way walls. Most of these sleeping lodges do not have decorative wall tiles except for the Ryokan Chic Hostel. Ryokan has printed pattern tiles attached to its five foot way wall under the ground floor windows. This tile was newly installed for this shop house's adaptive reuse conversion to a sleeping lodge (Figure 8).

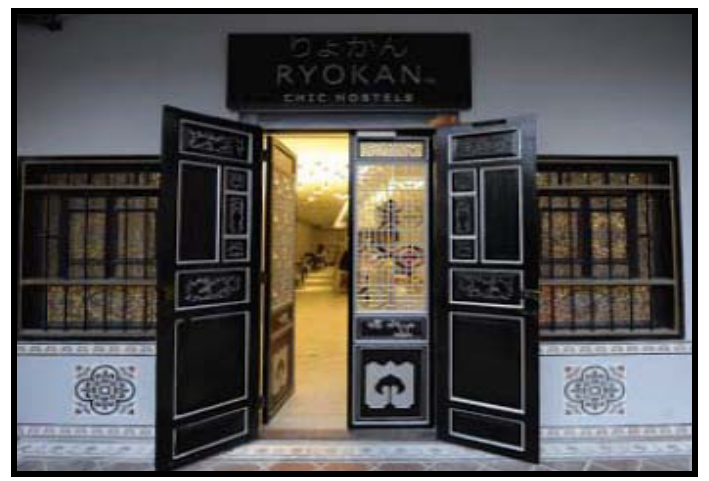

Figure 8: Printed pattern tiles on the five foot way wall of the Ryokan Chic Hostel

For the flooring of the five foot way, Syok Hostel, Red Inn Heritage and Ryokan use terracotta tiles either in an "I" or diamond shape. Whereas, for the other two sleeping lodges, Rainbow Lodge and Red Inn Heritage use Encaustic tiles for their five foot way floor finishes. Only Red Inn Court has used coloured cement finishes for their five foot way. Granite steps and a bridge across the drain have been used for all these sleeping lodges except for Ryokan (Figure 9). Ryokan has constructed a new, additional, burnt clay brick platform in front of the five foot way. Unfortunately, this platform automatically blocks the five foot way and, as stated in the guidelines; any blockage with a fixed obstruction is not allowed (Figure 10).

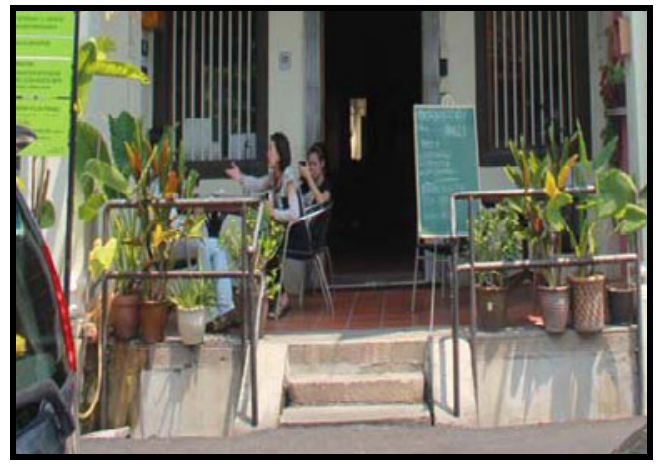

Figure 9: Example from Red Inn Heritage: terracotta tiles with granite steps and a bridge across the drain

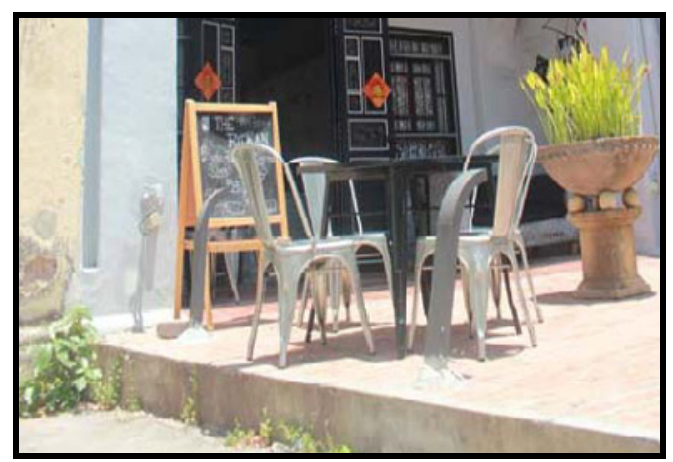

Figure 10: Ryokan Chic Hostel with its burnt clay brick platform in front of the five foot way

\subsection{Kitchen Courtyard and Air Well - Rear Court}

None of these case studies has a proper kitchen, such as a gas stove, because they are not allowed to do so. Heavy cooking activity could create a high risk of fire. Therefore, most of them just let this 
area vacant without any without any specific use. For the Rainbow Lodge, corrugated polycarbonate roofing is used to allow natural light to enter into this space. This roof was installed to give shade because wet clothing is hung there to dry. However, natural ventilation cannot penetrate this space unless the door is left open because Rainbow Lodge has fully covered air well in this area with a corrugated polycarbonate roof (See Figure 11). Unfortunately, Red Inn Heritage has not installed a proper roof. A roof similar to that at Rainbow Lodge is being used, but the roof only covers a small space which is used for hanging clothing to dry (Figure 12).

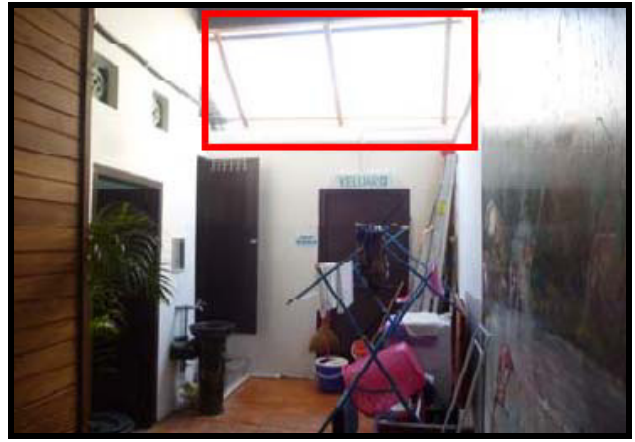

Figure 11: Corrugated polycarbonate as a roof cover for Rainbow Lodge

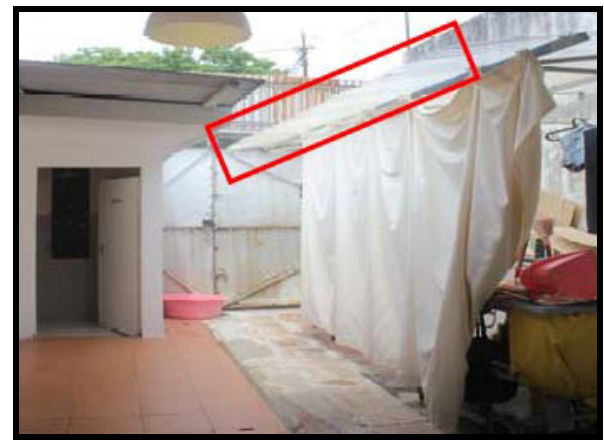

Figure 12: Corrugated polycarbonate as a roof cover for Red Inn Heritage being used as a cover for a clothes drying area

For the Ryokan Chic Hostel and Syok Hostel, this space has been left empty, without any obstacle or roofing system. This is the best choice because this area usually has a lot of toilets and good, natural ventilation is needed so that any odours can leave the space. The other two sleeping lodges, Red Inn Court and Red Inn Penang, do not have any kitchen courtyard or air well. So far, only Syok Hostel has followed the requirements from BOMBA because they have provided an external staircase. Leading to the back lane, this external staircase is needed as a means of escape. The measurements of the staircase are also certified by BOMBA. Furthermore, this staircase is made from steel in order to diminish the risk from fire (Figure 13).
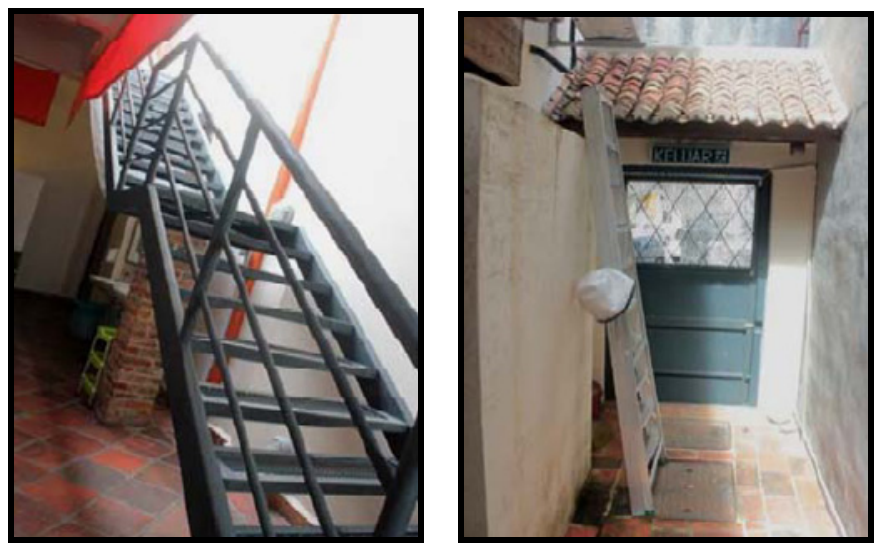

Figure 13: External staircase used as a means of escape to the back lane

\subsection{Rear Facade}

Normally, the rear facade will have a simpler opening than the fancy front façade. However, the material should remain same. This is different with these six case studies which present many changes with new opening materials. Usually, materials will be used that can be easily obtained nowadays such as steel doors and tempered glass windows. The use of tempered glass windows may happen 
because of the factor of air-conditioning use in sleeping lodges. For example, the Red Inn Court uses fixed tempered glass windows, fixed on the rear facade at the upper level. This is situated on the back side of the guest room with the air-conditioning system inside (Figure 14).
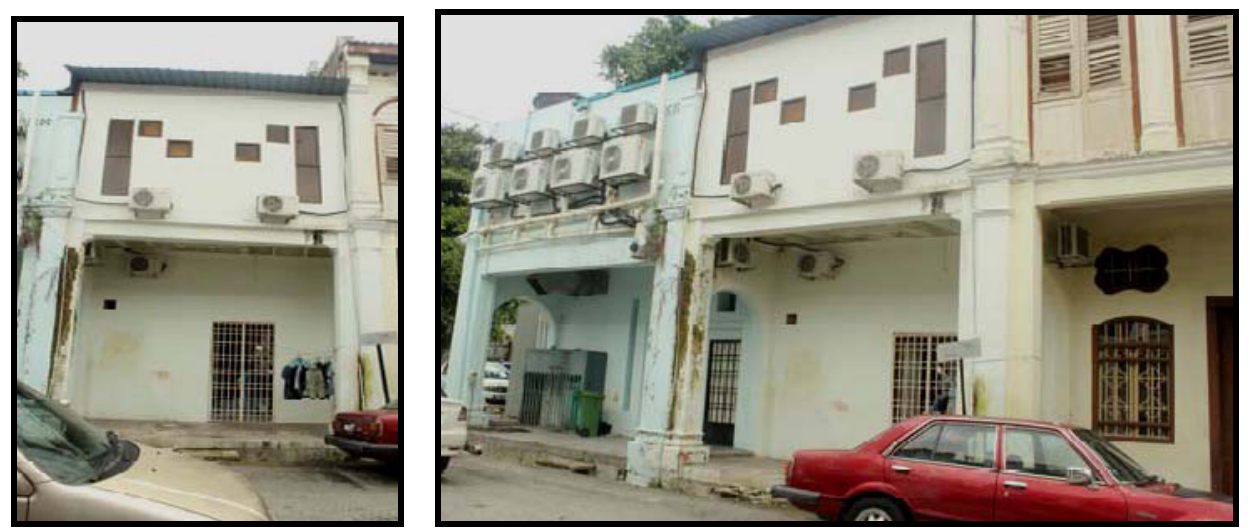

Figure 14: The appearance of the rear façade and the opening which is totally different from the front façade and adjacent buildings

At the moment, only the Ryokan Chic Hostel has constructed a new, additional rear boundary wall. This boundary wall does not have any doors for outward access. Therefore, it is quite dangerous in the event of a fire in this building because there is no means of escape provided at the back. Additionally, Ryokan has also wrongly designed the exit door on the upper floor of the rear facade where there is no walkway or steps to reach the ground below. Should a fire occur, the possibility of victims falling down from a great height is greater than those who will escape from the fire (Figure 15).

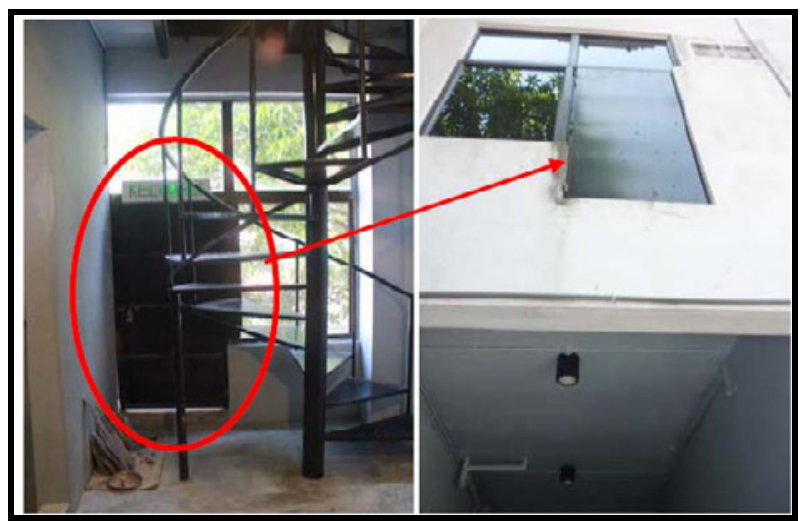

Figure 15: Exit door on the upper floor and how it looks from the rear facade

\section{Conclusion}

This paper has presented the results of vital clauses and components that have been extracted from the Draft George Town Special Area Plan as well as observations done from six adaptive reuse heritage shop houses in George Town, Penang. After having analysed the collected data, a few conclusions have been made. First, none of these six case studies have fully followed the requirements stated in the guidelines. Second, most of the building owners were simply concerned with the exterior part of the building, but when it came to the interior, many important things were being ignored. Third, some owners wanted to make the building traditional on the outside and modern on the inside, but the result was that the modern elements ruined the traditional features. Fourth, for the sake of doing business, 
owners have endangered guests' lives with faulty and hazardous design. Lastly, there exists a great lack of active fire protection and overemployment of passive fire protection in these buildings. This study not only increases awareness of heritage shop house conversion practices, but has also revealed a number of faults in the process that require serious attention.

\section{Acknowledgement}

The authors would like to thank the funding bodies of this research: Universiti Sains Malaysia under USM Short Term Grant. No. 304/PPBGN/6312147

\section{References}

1. A. Ghafar Ahmad, 2006. Cultural Heritage of Southeast Asia: Preservation for World Recognition. Journal of Malaysian Town Plan, 3 (1): 52-56

2. Norlizaiha Harun, 2011. Heritage Building Conservation in Malaysia: Experience and Challenges. [Online] Available from: http://kota-city.blogspot.com/2011/04/heritage-buildingconservation-in.html [Accessed $27^{\text {th }}$ October 2013].

3. M.A. Othuman Mydin, N. Md Sani, M. Taib, N. Mohd Alias, " Imperative Causes of Delays in Construction Projects from Developers' Outlook," MATEC Web Of Conferences, Volume 10, 06005.

4. Brit Kayan, 2014.Building Maintenance in Old Buildings Conservation Approach. Journal of Design and the Built Environment, pp: 42-32

5. S.W. Tan, M.A. Othuman Mydin, N. Md Sani, M.Z. Sulieman, "Investigation into Common Decay of Educational Buildings in Malaysia," MATEC Web Of Conferences, Volume 10, 05001.

6. Chow Kon Yeow, 2012. Over 800 heritage buildings have been sold since George Town was inscribed on UNESCO's World Heritage List. But are they being properly restored? [Online] Available from: http://www.thestar.com.my/story.aspx/?file=\%2f2012\%2f9\%2f2\%2fnation $\% 2 \mathrm{f} 11903362$. [Accessed 10 $0^{\text {th }}$ November 2013].

7. Lim Guan Eng, 2009. Hotels get go-ahead. [Online] Available from: http://www.thestar.com.my/Story/?file=\%2F2009\%2F1\%2F6\%2Fnation\%2F2948362. [Accessed $10^{\text {th }}$ November 2013].

8. M.A. Othuman Mydin, N. Md Sani, N.F. Abas, Y.Y. Khaw, "Evaluation of Fire Hazard and Safety Management of Heritage Buildings in Georgetown, Penang," MATEC Web Of Conferences, Volume 10, 06003.

9. Wun Thiam Yew, 2014. Introduction to Research Methodology. Professional and Personal Development Workshop

10. K. Syahril Kamal, 2008. Categories and Styles of Shop houses and Townhouses in Malacca and George Town, Malaysia. [Online] Available from: http://buildingconservation. blogspot.com/2009/01/categories-of-shophouses-at-malacca.html.

11. M.A. Othuman Mydin, N. Md Sani, A.F. Phius, "Investigation of Industrialised Building System Performance in Comparison to Conventional Construction Method," MATEC Web Of Conferences, Volume 10, 04001

12. M.A. Othuman Mydin, N. Md Sani, M. Taib, " Industrialised Building System in Malaysia: A Review," MATEC Web Of Conferences, Volume 10, 01002 